\title{
Iron stress and genetic response in cyanobacteria : fur genes from Synechococcus PCC 7942 and Anabaena PCC 7120
}

\author{
J.A. Hernández ${ }^{1}$, \\ M. Artieda ${ }^{1}$, \\ M.L. Peleato ${ }^{1}$, \\ M.F. Fillat ${ }^{1}$ \\ M.T. Bes ${ }^{1}$
}

Keywords : ferric uptake regulator (fur), iron, cyanobacteria.

Fur (Ferric uptake regulator) is a DNA-binding protein which represses the transcription of iron-regulated promoters using $\mathrm{Fe}^{2+}$ as a cofactor. In Gram negative bacteria, fur controls the expression of toxins and virulence factors when facing iron-stress: Iron is a key element limiting the growth and proliferation of phytoplankton. We have cloned the fur-gene from the cyanobacterium Synechococcus PCC 7942, applying the polymerase chain reaction (PCR) technique. The DNA fragments amplified encodes a Fur-type protein, which conserves the main motifs found in the family of Fur proteins. Recombinant Fur protein was successfully overproduced, reaching about $15 \%$ of the total protein content. Also, a Fur protein was identified in the filamentous, nitrogen-fixing cyanobacterium Anabaena PCC 7120.

\section{Réponse génétique au stress ferrique chez les Cyanobactéries : les gènes fur de Synechococcus PC 7942 et Anabaena PCC 7120}

Mots-clés : ferric uptake regulator (fur), fer, cyanobactérie.

Fur (Ferric uptake regulator) est une protéine d'union à l'ADN qui réprime la transcription des promoteurs régulés par le fer, utilisé sous forme $\mathrm{Fe}^{2+}$ comme cofacteur. Chez les bactéries Gram négatif, fur controle l'expression des toxines et des facteurs de virulence lors de stress ferrique. Le fer est un élément fondamental qui limite la croissance et la prolifération du phytoplancton. Nous avons cloné le gène fur de la cyanobactérie Synechococcus PCC 7942, en appliquant la technique de la réaction en chaîne de la polymérase (PCR). Le fragment d'ADN exprime une protéine de la famille de Fur qui conserve les motifs principaux trouvés dans cette famille. La protéine Fur de Synechocaccus a été produite avec succès, avec un rendement important de l'ordre de $15 \%$ du contenu total des protéines. De plus, une autre protéine Fur a été identifiée dans une cyanobactérie filamenteuse fixative d'azote : Anabaena PCC 7120.

\section{Introduction}

Iron is the most important micronutrient used by microorganisms. Living beings have selected iron to act as a cofactor in a large number of enzymes and achieve several important biological processes (Crichton 1991), such as respiration, photosynthesis, dinitrogen

\footnotetext{
1. Departamento de Bioquímica y Biología Molecular y Celular. Facultad de Ciencias. 50009 - Zaragoza, Spain.
}

fixation or ribonucleotide synthesis. The unique suitability of iron comes from the extreme variability of the $\mathrm{Fe}^{3+} / \mathrm{Fe}^{2+}$ redox potential which can be finely tuned by well-chosen ligands.

Although iron is one of the most abundant elements in Earth, it is not readily accesible to bacteria (Lewin 1984). Poor solubility in aqueous media and easy oxidation in aerobic atmospheres lead to the formation of unsoluble hydroxides, which bacteria are unable to acquire. Its availability for microbial uptake is an important variable in determining the stability and composition of aquatic ecosystems. 
However, an excess of iron is toxic because of its ability to catalyse formation of reactive species of oxygen (Halliwell \& Gutteridge 1984): Iron uptake has to be, therefore, exquisitely regulated to maintain the intracellular concentration of the metal between desirable limits. Considering that excretion mechanisms for iron are not known in bacteria, microorganisms appear to control iron homeostasis by regulating its transport through the membrane (Bagg \& Neilands 1987).

Iron limitation has profound consequences for all microbial organisms so far identified on our planet. The limitation of soluble, biologically useful iron in aerobic environments, where the bulk of life resides on Earth, is as much a dilemma to planktonic microorganisms trying to sustain themselves in vast areas of the South Pacific (Behrenfeld \& Kolber 1999). Species with stronger iron uptake systems would be able to preferentially use the available iron, as happens when microbial pathogens attempt to initiate and sustain commensal or pathological relationships with other organisms (Crosa 1997). The lack of iron is a major environmental signal that triggers expression of virulence determinants (Litwin \& Calderwood 1993).

Iron availability and biolimitation by iron have been an important focus of discussion for oceanographers and limnologists. After the IronEx II (Coale et al. 1996, Behrenfeld et al. 1996 ; Kirchman 1996) it was established that deprivation of iron unequivocally limits cell division rates, abundance and production rate in phytoplankton (Frost 1996). Moreover, iron nutritional status of phytoplankton is of great interest, while toxin production (Lyck et al. 1996) or undesirable blooms of cyanobacteria may be related to iron availability (Behrenfeld et al. 1996).

Cyanobacteria species have developed several mechanisms to avoid iron stress. They are able to produce powerful iron-binding compounds (siderophores) (Crosa 1989, Neilands 1989). Siderophore chelators can suppress growth of competing species in lake waters (Murphy et al. 1976). Cyanobacteria can also synthesize new proteins which substitute those proteins requiring iron to develop their function (flavodoxinferredoxin system, which has been used as a molecular marker of iron-stress) (Sandmann et al. 1990).

At a molecular level, cells must sense intracellular concentration of free iron and couple it to gene expression. The key element in this response, for cyanobacteria and Gram-negative bacteria, is a DNA-binding metaloprotein called Fur (Ferric uptake regulator). This protein, encoded by the fur gene, is able to repress the transcription of iron-regulated promoters in response to an increasing intracellular $\mathrm{Fe}^{2+}$ concentration. It has been found that Fur binds to control sequences (fur boxes) (Escolar et al. 2000) overlapping Fur-regulated promoters when the intracellular concentration is high enough to allow the formation of a complex consisting of a Fur dimer and $\mathrm{Fe}^{2+}$.

In cyanobacteria, Fur protein is the key element controlling expression of a number of Fur-regulated genes, such as siderophore biosynthesis enzymes or flavodoxin protein. However, the interest in Fur is not only the participation in most iron-dependent cellular systems. Also crucial functions have been found to be related with oxidative stress (Nunoshiba et al. 1999), acidic stress (Hall \& Foster 1996) or toxin production in heterotrophic bacteria (Somerville et al. 1999).

Fur protein was first identified in Salmonella typhimurium (Ernst et al. 1978) and has been most extensively characterized in Escherichia coli. Fur homologues have been found in several other.Gram negative bacteria, including some important human pathogens like Pseudomonas (Prince et al. 1993), Vibrio (Litwin et al. 1992), Neisseria (Thomas \& Sparling 1994), Yersinia (Staggs \& Perry 1991), Helicobacter pylori (Bereswill et al. 1998), Bordetella (Brickman \& Armstrong 1995), Campylobacter (Wooldridge et al.1994), Acinetobacter baumannii (Daniel et al. 1999), Legionella (Hinkey \& Cianciotto 1994) or Haemophilus (Carson et al. 1996). However, Fur has not been deeply investigated in cyanobacteria, having only been described in the unicellular cyanobacteria $S y$ nechocystis PCC 6803 (Kaneko et al. 1996) and Synechoco'ccus PCC 7942 (Ghassemian \& Straus 1996), which are unable to fix nitrogen.

Our purpose is to characterise the product of the fur gene in cyanobacteria, since the Fur protein might be the key element controlling the expression of genes involved in cyanotoxin production, secondary metabolites produced by cyanobacteria which have hepatotoxic or neurotoxic effects on different species. Fur might be involved as well in the control of the occurrence of cyanobacterial blooms depending of the environmental iron level. With this purpose, we have amplified and overexpressed the Fur protein from the unicellular eyanobacterium Synechococcus PCC 7942. Moreover, a fur gene has also been identified in the filamentous nitrogen fixing cyanobacterium Anabaena $\mathrm{sp}$. The high level of the expression system, about $20 \%$ of the total protein content of the recombinant $E$. coli strain was Fur from Synechococcus, makes it very suitable for functional and structural studies of this protein whose three dimensional structure remains still unsolved. 


\section{Material and methods}

\subsection{Bacterial strains, plasmids and culture media}

Genotypes and sources of the bacterial strains and plasmids used in this study are described in Table 1.

Synechococcus PCC 7942 was grown in BG11 medium liquid culture (Rippka et al. 1979).

\subsection{PCR amplification and cloning of Synechococ- cus fur gene}

The fur gene from Synechococcus was amplified by means of the polymerase chain reaction (PCR) using a Perkin Elmer Cetus DNA Thermal Cycler. Chromosomal DNA from Synechococcus PCC.7942 was isolated according to Cai \& Wolk.(1990), and used as a templa- te for PCR reaction. Synthetic oligonucleotides, designed according to the fur sequence reported by Ghassemian \& Straus (1996), were used to generate doublestranded DNA in addition to restriction enzyme sites for cloning. The forward primer 5'- GACTCGCCATGGCCTACACAGCG-3' carried a NcoI restriction site. The reverse primer 5'-GCGGAAGCTTCGCTAGCTGCACC-3' carried a HindIII restriction site. The reaction mix contained $0.5 \mu \mathrm{M}$ of each sense and antisense primer, $200 \mu \mathrm{M}$ of each dNTP, $1.5 \mathrm{mM}$ $\mathrm{MgCl}_{2}$ and $2.5 \mathrm{U}$ of Taq DNA. Amplification was carried out as follows : denaturation at $95^{\circ} \mathrm{C}$ for $3 \mathrm{~min}$., then 30 cycles at $93^{\circ} \mathrm{C}(0.5 \mathrm{~min}$.) for denaturation, annealing at $65^{\circ} \mathrm{C}(1 \mathrm{~min}$.$) and extension at 72^{\circ} \mathrm{C}(1$ min.). A final extension step at $72^{\circ} \mathrm{C}$ was performed for $10 \mathrm{~min}$.

Table 1. Bacterial strains and plasmids.

Tableau 1. Souches bactériennes et plasmides.

\begin{tabular}{|c|c|c|}
\hline Bacterial strains and plasmids & Relevant characteristics & Source or reference \\
\hline \multicolumn{3}{|l|}{ Strains } \\
\hline \multicolumn{3}{|l|}{$\underline{\text { E.coli }}$} \\
\hline JM109 & 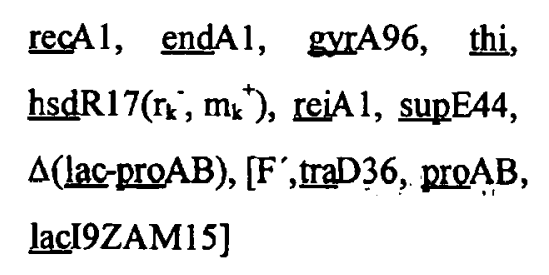 & Messing et al. 1981 \\
\hline BL21-DE3 strain & $\begin{array}{l}\mathrm{F}^{*} \underline{\mathrm{dcm}} \stackrel{\mathrm{omp}}{\mathrm{T}} \underline{\mathrm{hsdS}}\left(\mathrm{r}_{\mathrm{B}} \mathrm{m}_{\mathrm{B}}\right) \mathrm{gal}, \\
\lambda(\mathrm{DE} 3)\end{array}$ & Stratagene \\
\hline \multicolumn{3}{|l|}{ Synechococcus } \\
\hline 7942 & $\begin{array}{l}\text { Synechecoccus sp. } \\
\text { strain PCC7942 }\end{array}$ & \\
\hline \multicolumn{3}{|l|}{ Plasmids } \\
\hline pGEM-T Easy & $\begin{array}{l}\text { Cloning vector with single } 3^{\prime}-\mathrm{T} \\
\text { overhanging at the insertion site. } \\
\text { It is flanked by recognition sites } \\
\text { for the restriction enzymes } \\
\text { EcoR, BsfZI and NotI }\end{array}$ & Promega \\
\hline $\mathrm{pET}-28 \mathrm{a}(+)$ & $\begin{array}{l}\text { Expression vector carrying an } \mathrm{N}- \\
\text { terminal } \\
\text { His } \bullet \text { Tag/thrombin } / \mathrm{T} 7 \cdot \mathrm{Taq} \\
\text { configuration plus an optional } \\
\text { C-terminal His } \bullet \text { Taq sequence }\end{array}$ & Novagen \\
\hline
\end{tabular}




\subsection{Sequencing of the DNA fragment}

The PCR product (a single band in agarose gels) was cloned, without further purification, into the pGEM®T Easy Vector System (Promega, Madison, WI). E.coli JM109 cells were transformed with these constructs. Sequencing in both directions was performed, using the Thermo Sequenase fluorescent labelled primer cycle sequencing kit (Amersham Pharmacia Biotech, UK) and an automated ALFexpress ${ }^{\text {TM }}$ DNA sequencer (Amersham Pharmacia Biotech, UK). Synthetic oligonucleotides used as primers for PCR and DNA sequencing were purchased from Pharmacia (Sweden).

\subsection{Construction of the Synechococcus fur gene ex- pression vector}

The pGEM®-T Easy/insert construct was digested with the restriction enzymes $\mathrm{Ncol}$ and HindIII to generate cohesive ends, and the digestion products separated in a $2 \%$ agarose gel. The band containing the furgene was purified (see Bes et al. 2000) and this DNA was cloned into the $\mathrm{NcoI}$ and HindIII cloning sites of the expression vector pET-28a(+) using T4-DNA ligase. E.coli BL21-DE3 cells were transformed with the construct $\mathrm{pET}-28 \mathrm{a}(+) / f u r$, and colonies were selected in Luria Bertani plates containing kanamycin ( 30 $\mu \mathrm{g} / \mathrm{ml}$ ). Automatic DNA sequencing was performed to confirm the sequence.

\subsection{Analysis of expressed Fur protein}

Several colonies containing the pET-28a(+)/fur plasmid were grown overnight in Luria Bertani medium supplemented with $30 \mathrm{mg} / \mathrm{ml}$ of kanamycin. After 14 hours of incubation with shaking at $37^{\circ} \mathrm{C}$, cultures were diluted 70 -fold in Luria Bertani medium containing $30 \mathrm{mg} / \mathrm{ml}$ of kanamycin. After 3 hours growth at $37^{\circ} \mathrm{C}$, when the absorbance at $600 \mathrm{~nm}$. had reached a value of 0,7-0,9, isopropyl $\beta$-D-thiogalactopyranoside (IPTG) was added to a final concentration of $1 \mathrm{mM}$. In control cultures, IPTG was omitted. Cells were allowed to growth at $37^{\circ} \mathrm{C}$, harvesting tubes 2 hours later. The level of expression was monitored by evaluating total protein content of different samples by electrophoresis on denaturing SDS-PAGE gels (Laemmli 1970) and further analysis with a Gel Doc 2000 image analyser from Bio-Rad.

\section{Results}

\subsection{Amplification and cloning of the fur gene from Synechococcus PCC 7942}

The Synechococcus fur-gene has already been cloned, by screening in a DNA library (Ghassemian \&
Straus 1996). In our work, we applied a different procedure, using PCR. Chosen oligonucleotides correspond to a sequence complementary to the beginning and to the end of Synechococcus fur-gene, modified to include NcoI and HindIII restriction sites in 5' and 3', respectively (Material and Methods).

PCR reactions were performed with this oligonucleotides, using total DNA from Synechococcus PCC 7942 as template. In this way, several PCR products were obtained, one of them showing similar weight than that of a putative fur-gene, approximately $450 \mathrm{pb}$. This PCR product was purified, cloned in the PGEM-T Easy plasmid and sequenced. The sequence was compared with fur-gene from Synechococcus PCC 7942, deposited in the GenBank database, and showed complete identity, except in one nucleotide. However, this did not imply any change in the protein sequence (Fig. 1).

\subsection{Identification of a fur homologue from Anabae- na PCC 7120}

In order to detect the presence of a Fur-like protein in Anabaena PCC 7120, we took into account the fact that for all microorganisms the described Fur proteins share regions fully conserved. This is the case of the HHXHXXCXXC motif (Hennecke 1990), a consensus sequence indispensable for the binding of the metal ion which activates Fur in order to interact with the DNA operator regions. This is an infrequent amino acid sequence which is not found in other protein families, probably because of the presence of several bulky amino acids consecutively placed. Using the computer sequence searching tools present in the CyanoBase, we searched for any sequence encoding the histidine motif characteristic of Fur proteins. We localized only one region in the complete genomic sequence of Anabaena PCC 7120 where this motif was contained in an open reading frame that presented all the characteristics of a fur gene. It is shown in the figure 2 , together with the deduced protein sequence.

\subsection{Sequence analysis of the identified fur genes}

The isolated fur gene from Synechococcus PCC 7942 was an open reading frame with only one nucleotide differing with the already reported sequence, but coding for the same 147 amino acid protein.

The sequence selected in the CyanoBase coding a fur-like gene from Anabaena PCC 7119 was an open reading frame coding for a sequence of 151 amino acids that was homologous to several Fur proteins and contained the putative iron-binding domain typical of Fur repressors family reported up to date, indicating 


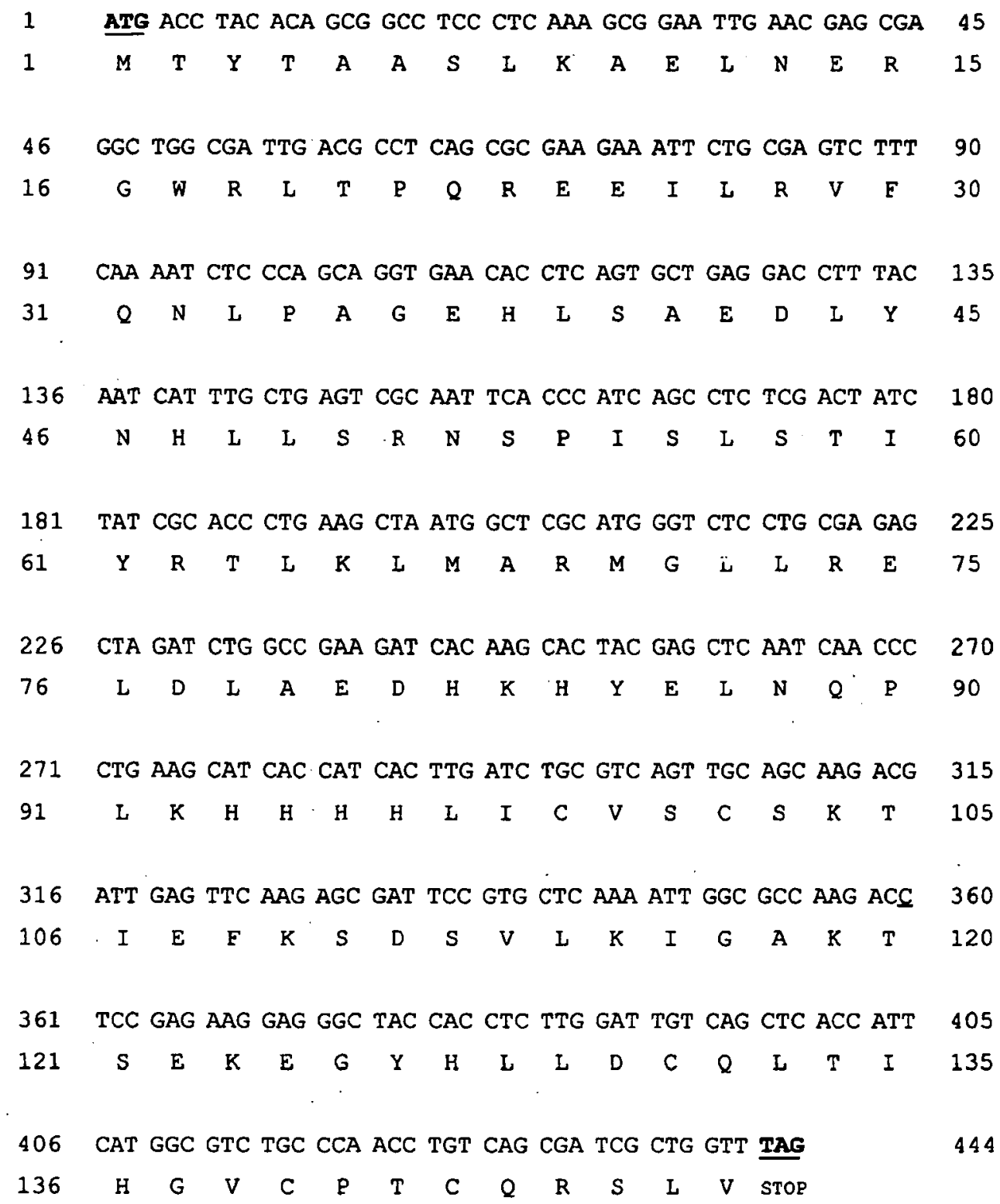

Fig. 1. Nucleotide sequence of Synechococcus PCC 7942 fur gene. The deduced amino acid sequence is shown below the nucleotide sequence in one-letter code. The nucleotides corresponding to the translational start site and stop site are in bold letters and underlined. The only nucleotide differing from the reported sequence is underlined.

Fig. 1. Séquence des nucléotides du gène fur de Synechococcus PCC 7942. La séquence déduite des acides aminés figure en dessous de la séquence des nucléotides, avec un code d'une lettre. Les nucléotides correspondant au début et à la fin de la traduction apparaissent en gras et soulignés. Le seul nucléotide qui diffère de la séquence existante est souligné.

that it was likely to encode a Fur protein. Fig. 2 shows the translated amino acid sequence encoded by the open reading frame from Anabaena, which was analyzed for homologous proteins in the SwissProt data base. Optimal alignment (Fig. 3) with the sequences of the two cyanobacterial Fur proteins available in the database shows the highest homology, $73 \%$, with the protein from Synechococcus, and a $66 \%$ homology with Fur from Synechocystis. Much lower homology was found with Fur from E.coli $(30 \%)$. This degree of dissimilarity can explain its lack of activity in Western blots treated with antiserum raised against Fur from E.coli (Figure 4B).

\subsection{Expression of Fur from Synechococcus in E.coli}

From the several expression systems that are available to overproduce foreign proteins in E.coli, the pET-28a(+) vector was the most efficient. This system is based on the strong promoter for RNA polymerase of the T7 phage (Novagen). When BL21-DE3 (Gold) E.coli cells transformed with the expression plasmid containing the fur-gene were induced to overexpress the gene, an increase in the level of synthesis of one of the proteins was observed at growing time intervals by SDS-PAGE. 
1 ATG GCT GTC TAC ACA AAT ACT TCG CTC AAG GCA GAA TTA AAC GAA 45

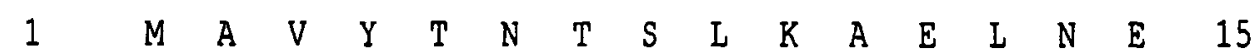

46 AGA GGC TGG CGT TTG ACC CCT CAA CGG GAA ACT ATC TTA CAT ATC 90

$\begin{array}{lllllllllllllllll}\text { 16. } & R & G & W & R & L & T & P & Q & R & E & T & I & I & H & I & 30\end{array}$

91. TTT CAA GAA CTT CCT CAA GGC GAA CAC CTG AGT GCA GAA GAT TTA 135

$\begin{array}{lllllllllllllllll}31 & F & Q & E & L & P & Q & G & E & H & \text { L } & S & A & E & D & L & 45\end{array}$

136 TAT CAT CGC TTG GAA GCT GAC GGT GAA GGA ATC AGC CTT TCA ACG 180

$\begin{array}{lllllllllllllllll}46 & Y & H & R & L & E & A & D & G & E & G & I & S & L & S & T & 60\end{array}$

181 ATT TAC CGG ACG TTG AAG TTG ATG GCT CGG ATG GGG ATT TTA CGT 225

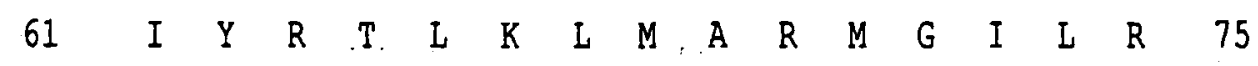

226 GAA CTG GAA TTA GGC GAA GGA CAC AAG CAC TAC GAA ATT AAC CAG 270

$\begin{array}{llllllllllllllllll}76 & \text { E } & \text { L } & \text { E } & \text { L } & G & \text { E } & \text { G } & \text { H } & \text { K } & \text { H } & \text { Y } & \text { E } & \text { I } & \text { N } & \text { Q } & 90\end{array}$

271 CCT TAT CCC CAT CAT CAC CAT CAC CTA ATT TGT GTC AAA TGT AAC 315

$\begin{array}{lllllllllllllllll}91 & \mathrm{P} & \mathrm{Y} & \mathrm{P} & \mathrm{H} & \mathrm{H} & \mathrm{H} & \mathrm{H} & \mathrm{H} & \mathrm{L} & \mathrm{I} & \mathrm{C} & \mathrm{V} & \mathrm{K} & \mathrm{C} & \mathrm{N} & 105\end{array}$

316 TCT ACT ATT GAA TTC AAA AAC GAT TCA ATC TTA AAA ATT GGG GCA 360

$\begin{array}{lllllllllllllllll}106 & S & T & I & E & F & K & N & D & S & I & L & K & I & G & A & 120\end{array}$

361 AAA ACT GCC CAG AAA GAA GGT TTT CAC CTA CTG GAC TGC CAA ATG 405

$\begin{array}{lllllllllllllllll}121 & K & T & A & Q & K & E & G & F & H & \text { L } & \text { L } & \text { D } & \text { C } & \text { Q } & \text { M } & 135\end{array}$

406 ACA ATT CAT GCA GTC TGC CCC AAG TGC CAA CGT GCG CTC ATG CCA . 450

$\begin{array}{lllllllllllllllll}136 & \mathrm{~T} & \mathrm{I} & \mathrm{H} & \mathrm{A} & \mathrm{V} & \mathrm{C} & \mathrm{P} & \mathrm{K} & \mathrm{C} & \mathrm{Q} & \mathrm{R} & \mathrm{A} & \mathrm{I} & \mathrm{M} & \mathrm{P} & 150\end{array}$

451 CTT TAG 456

151 L STOP

Fig. 2. Nucleotide sequence of Anabaena PCC 7120 fur gene. The deduced amino acid sequence is shown below the nucleotide sequence in one-letter code. The nucleotides corresponiding to the translational start site and stop site are in bold letters and underlined.

Fig. 2. Séquence des nucléotides du gène fur d'Anabaena PCC 7120. La séquence déduite des acides aminés figure en dessous de la séquence des nucléotides, avec un code d'une lettre. Les nucléotides correspondant au début et à la fin de la traduction apparaissent en gras et soulignés. 
Alignment of several Fux proteins : CLUSTAL $W$ (1.8) multiple sequence alignment

Anabaena PCC7119

Synechococcus PCC7942

Synechocystis PCC6803

E.coli

Anabaena PCC7119

Synechococcus PCC7942

Synechocystis PCC6803

E.coli

Anabaena PCC7119

Synechococcus PCC7942

Synechocystis PCC6803

E.Coli

\begin{abstract}
MTVYTNTSLKAELNERGWRLTPQRETILHIFOELPOGEHLSAEDLYHRLEADGEGISLST 60 -MTYTAASLKAELNERGWRLTPQREEILRVFQNLPAGEHLSAEDLYNHLLSRNSPISLST 59 -MSYTADSLKAELNARGWRLTPOREKILTIFONLPEGEHLSAEELHHRLEEEREKISLST 59 ----MTDNNTALKKAGLKVTLPRLKILEVLQ-EPDNHHVSAEDLYKRLIDMGEEIGLAT 54

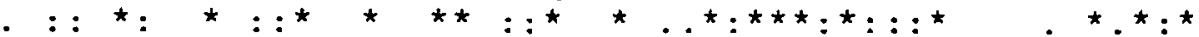

IYRTLKLMARMGILRELELGEGHKHYEINQPYPHHHHHLICVKCNSTIEFKNDSILKIGA 120 IYRTLKLMARMGLLRELDLAEDHKHYELNQP-LKHHHHLICVSCSKTIEFKSDSVLKIGA 118 VYRSVKLMSRMGILRELELAEGHKHYELOOAS PHHHHHVVCVOCNRTIEFKNDSILKOSL 119 VYRVLNQFDDAGIVTRHNFEGGKSVFELTQQ--HHHDHLICLDCGKVIEFSDDSIEARQR 112

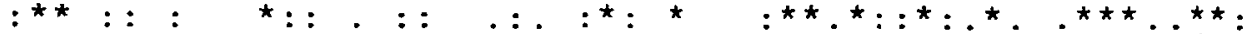

KTAQKEGFHLLDCQMTIHAVCPKCQRALMPL_-_...- - 151 KTSEKEGYHLLDCQLTIHGVCPTCQRSLV_-_..........- 147 KQCEKEGFQL IDCQLTVTT ICPEAIRMGWPSTLPSNWACTRSISLA 165 EIAAKHGIRLTNHSLYLYGHCAEGDCREDEHAHEGK_...... 148 $:{ }^{\star} \cdot{ }^{\star}:{ }^{\star}:$ : : : .

Fig. 3. Multiple sequence alignment. Sequence alignment was obtained by using the Clustal W (version 1.8) program.

Fig. 3. Alignement multiple des séquences. L'alignement a été effectué à l'aide du programme Clustal W (version 1.8).

In Figure 4A, the overexpression of the Fur protein from Synechococcus is presented. A new band with a mobility of $15.4 \mathrm{kDa}$ was found after 2 hours from induction, even though some residual expression was present in absence of IPTG. Densitometric scans indicate that Fur represents at least $20 \%$ of the total protein content in the host cells.

The mobility of the putative Fur band, about 17.4 $\mathrm{kDa}$, is fairly coincident with the theoretical molecular weight of $16.8 \mathrm{kDa}$ for the Synechococcus protein.

\section{Discussion}

Iron availability has been thought as the limitant element for microorganisms growth. After the IronEx II (Coale et al. 1996, Behrenfeld et al. 1996, Kirchamn 1996), this hypothesis was definitively established : iron unequivocally limits cell division rates, abundance and production rate in phytoplankton (Frost 1996). This fact has lead to the use of remarkably sophisticated mechanisms to scavenge iron from the sources in the environment where microorganisms reside.

Cyanobacteria are one of the most ancient groups of bacteria living in Earth. Throughout their evolution, they have developed a large number of systems to take advantage in competitive media, such as dinitrogen fixation, high ability to retain phosphorus or $\mathrm{CO}_{2}$, gas vesicle to regulate their flotation, formation of high resistance forms (akinetes) or the existence of exceptionally developed iron-uptake systems. Altogether, these factors make cyanobacteria successful in the use of en- vironmental nutrients, made clear by the appearance of cyanobacterial blooms. In fact, sudden dominance of cyanobacteria in eutrophic lakes coincided with the production of strong iron chelators and the rapid uptake of iron (Murphy et al. 1976).

Cyanotoxin production can also be related to iron availability. It has been shown (Utkilen \& Gjolme 1995) that toxin synthesis increases together with iron concentration, suggesting that toxins could act as an intracellular chelator which keeps the cellular level of free iron low. However, an opposite relationship between toxin production and iron concentration has also been reported (Lukac \& Aegerter 1993). Whether cyanotoxin production can also be considered as another cyanobacterial response to ferric-stress, in order to eliminate competitors and enrich iron content in the medium, remains to be investigated. In this way, Fur might play a key role in sensing intracellular iron contents and regulating expression of peptide and polyketide synthetases involved in cyanotoxin production. A deep study of their promoters and regulation of gene expression should be performed to a complete understanding of toxin function in cyanobacteria.

In this work, we report the cloning and overexpression of the Fur protein from unicellular cyanobacterium Synechococcus PCC 7942. Moreover, a sequence highly homologous to the fur-gene has also been found in the genome of the nitrogen-fixing Anabaena PCC 7119 (filaments former). Their sequences show significant homology with all the Fur sequences known in 
A

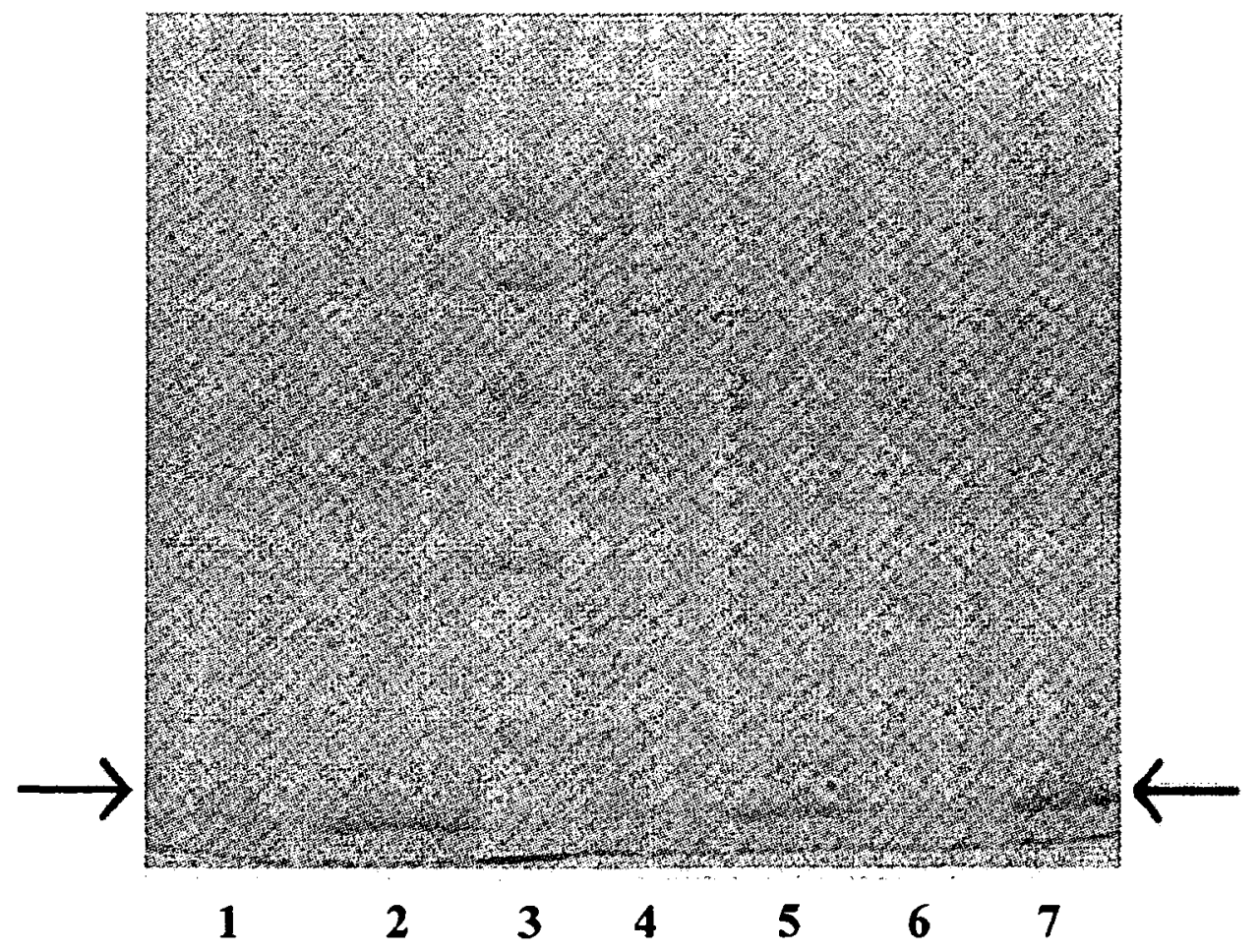

B

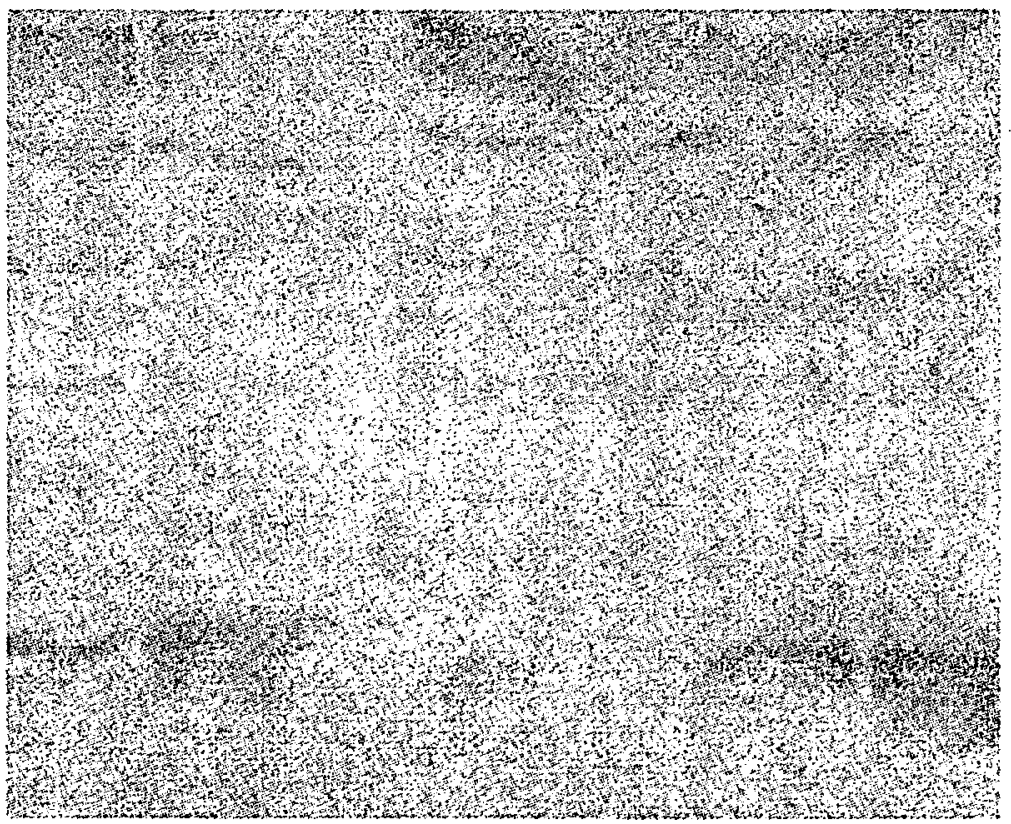

Fig. 4. SDS-PAGE and Western-blot analysis of the expression and cross-reactivity of Fur from Synechococcus PCC 7942.

A : SDS-PAGE in a $20 \%$ polyacrilamide gel, showing overexpression of the protein collected at different times. Lanes 1,4 and $6:$ cells with plasmid carrying the fur gene collected at 0 min. Lanes 2,5 and 7 : cells with plasmid carrying the fur gene collected 120 min. after induction. Lane 3, molecular weight markers (in Kda.) 94, 67, 43, 30, 20.1 and 14.4.

B: Western-blot of the same gel as in figure 4A, transferred to a PVDF membrane and developed with antibodies raised against Fur from E.coli. A band from E.coli Fur appears in all lanes, but no band corresponding to the Fur protein from Synechococcus was seen, showing that there is no cross-reaction of anti-Fur from E.coli with Fur from Synechococcus.

Fig. 4. Résultats des analyses du SDS-PAGE et du Western Blot, quant à l'expression et la réactivité croisée de la protéine Fur de Synechococcus.

A : Le test SDS-PAGE a été réalisé dans un gel de $20 \%$ de polyacrilamide, montrant la protéine produite collectée à différents intervalles de temps. Pistes 1,4 et $6:$ les cellules avec le plasmide et le gène fur collectés au temps 0 . Pistes 2,5 et $7:$ les cellules avec le plasmide et le gène fur collectés $120 \mathrm{~min}$. après l'induction. Piste 3, marqueur du poids moléculaire (en Kda.) 94, 67, 43, 30, 20,1 et 14,4.

$\mathrm{B}$ : Western-blot du gel de la figure 4A, transferé à une membrane PVDF et révélé avec des anticorps préparés contre Fur de $E$.coli. La bande de Fur de E.coli apparaît dans toutes les pistes, mais il n'y a aucune bande de la protéine Fur de Synechococcus, ce qui montre qu'il n'y a pas eu de réaction croisée entre les anti-Fur du E.coli et la protéine Fur de Synechococcus. 
cyanobacteria, and low homology with E. coli Fur sequence.

Future work will focus on characterization of Fur protein and further work about Fur binding with suitable gene promoters, including those involved in cyanotoxin production.

\section{References}

Bagg A. \& Neilands J.B. 1987. - Ferric uptake regulation protein acts as a repressor, employing iron (II) as a cofactor to bind the operator of an iron transport operon in Escherichia coli. Biochemistry, $26:$ 5471-5477.

Behrenfeld M.J., Bale A.J., Kolber Z.S., AikenJ. \& Falkowsk P.J. 1996 - Confirmation of iron limitation of phytoplankton photosynthesis in the equatorial Pacific Ocean. Nature, $383: 508-511$.

Behrenfeld M.J. \& Kolber Z.S. 1999. — Widespread iron limitation of phytoplankton in the South Pacific ocean. Science, 283 : 840-843.

Bereswill S., Lichte F., Vey T., Fassbinder F. \& Kist M. 1998. Cloning and characterization of the fur gene from Helicobacter pylori. FEMS Microbiol. Lett., 159 : 193-200.

Brickman T.J \& Armstrong S.K. 1995. - Bordetella pertussis fur gene restores iron repressibility of siderophore and protein expression to deregulated Bordetella bronchiseptica mutants. $J$. Bacteriol., $177: 268-270$.

Cai Y. \& Wolk C.P. 1990. - Use of a conditional lethal gene in Anabaena sp. strain PCC 7120 to select for double recombinants and to entrap insertion sequences. J. Bacteriol., $172: 3138-3145$.

Carson S.D.B., Thoma C.E. \& Elkins C. 1996. - Cloning and sequencing of a Haemophilus ducreyi fur homolog. Gene, 176 : 125-129.

Crichton R.R. 1991. - Inorganic biochemistry of iron metabolism. Ellis Horwood. Chichester, 263 p.

Crosa J.H. 1989. - Genetics and molecular biology of siderophore mediated iron transport in bacteria. Microbiol. Reviews, 53 : 517-530.

Crosa J.H. 1997. - Signal transduction and transcriptional and posttranscriptional control of iron-regulated genes in bacteria. Microbiol. Mol. Biol. Rev., 61 : 319-336.

CyanoBase Website : [Online]http://www.kazusa.or.jp/cyano. 2000, last date accessed.

Daniel C., Haentjens S., Bissinger M.C. \& Courcol R.J. 1999. Characterization of the Acinetobacter baumanni Fur regulator : cloning and sequencing of the fur homologue gene. FEMS Microbiol. Lett., 170 : 199-209.

Ernst J.F., Bennett R.L. \& Rothfield L.I. 1978. - Constitutive expression of the iron-enterochelin and ferrichrome uptake systems in a mutant strain of Salmonella typhimurium. J.Bacteriol., 135 : 928-934.

Escolar L., Pérez-Martín J. \& de Lorenzo V. 2000. — Evidence of an unusually long operator for the Fur (ferric uptake) repressor in th eaerobactin promoter of Escherichia coli. J. Biol. Chem., 275 : 24709-24714.

Frost B.W. 1996. - Photoplankton bloom on iron rations. Nature, $38: 475-476$.

Ghassemian M. \& Straus N.A. 1996. - Fur regulates the expression of iron-stress genes in the cyanobacterium Synechococcus sp. strain PCC 7942. Microbiology., 142 : 1469-1476.

Hall H.K. \& Foster J.W. 1996. - The role of Fur in the acidic tolerance response of Salmonella typhimurium is physiologically and genetically separable from its role in iron acquisition. J. Bacteriol., $179: 5683-5691$.
Halliwell B. \& Gutteridge M.C. 1984. - Oxygen toxicity, oxygen radical, transition metals and disease. Biochem J., $219: 1-14$.

Hennecke H. 1990. - Regulation of bacterial gene expression by metal-protein complexes. Mol. Microbiol., 4 : 1621-1628.

Hinkey E.K. \& Cianciotto N.P. 1994. - Cloning and sequencing of the Legionella pneumoniae fur gene. Gene, $143: 117-121$.

Kaneko T., Sato S., Kotani H., Tanaka A., Asamizu E., Nakamura Y., Miyajima N., Hirosawa M., Sugiura M., Sasamoto S., Kimura T., Hosouchi T., Matsuno, Muraki A., Nakazaki N., Naruo K., Okumura S., Shimpo S., Takeuchi C., Wada T., Watanabe A., Yamada M., Yasuda M. \& Tabata S. 1996. - Sequence analysis of the genome of the unicellular cyanobacterium Synechocystis sp. strain PCC 6803. II. Sequence determination of the entire genome and assignment of potential protein coding regions (supplement). DNA Res., 3 : 185-209.

Kirchamn D.L. 1996. - Microbial ferrous wheel. Nature, 383 : 303-304.

Laemmli U.K. 1970. - Cleavage of structural proteins during the assembly of the head of bacteriophage T4. Nature, $227: 680-685$.

Lewin R. 1984. - How microorganisms transport iron. Science, 225 : 401-402.

Litwin M. \& Calderwood S.B. 1993. - Role of iron in regulation of virulence genes. Clin. Microbiol. Reviews, $6: 137-149$.

Litwin M., Boyko S.A. \& Calderwood S.B. 1992. - Cloning, sequencing and transcriptional regulation of the Vibrio cholerae fur gene. J. Bacteriol., 174 : 1897-1903.

Lukac M. \& Aegerter R. 1993. - Influence of trace metals on growth and toxin production of Microcystis aeruginosa. Toxicon., 293-305

Lyck S., Gjolme N. \& Utkilen H. 1996. - Iron starvation increases toxicity of Microcystis aeruginosa CYA 228/1 (Chroococcales, Cyanophyceae). Phycologia, $35:$ 120-124.

Murphy T.P., Lean D.R.S. \& Nalewajko C. 1976. - Blue-green algae : their excretion of iron-selective chelators enables them to dominate other algae. Science, $192: 900-902$.

Neilands J.B. 1989. - Siderophores systems of bacteria and fungi. In T.J. Beveridge \& R.J. Doyle (eds), Metal ions and bacteria. John Wiley \& Sons, Inc., New York : 141-163.

Nunoshiba T., Obata F., Boss A.C., Oikawa S., Mori T., Kawanishi S. \& Yamamoto K. 1999. - Role of iron and superoxide for generation of hydroxyl radical, oxidative DNA lesions and mutagenesis in Escherichia coli. J. Biol. Chem., $274: 34832-34837$.

Prince R.W., Cox C.D. \& Vasil M.L. 1993. - Coordinate regulation of siderophore and exotoxin A production : molecular cloning and sequencing of the Pseudomonas aeruginosa fur-gene. J. Bacteriol., $175: 2589-2598$.

Rippka R., Deruelles J., Waterbury J.B., Herdman M. \& Stainer R.Y. 1979. - Generic assignments, strain histories and properties of pure cultures of cyanobacteria. J. Gen. Microbiol., 111 : 1-61.

Sandmann G., Peleato M.L., Fillat M.F., Lázaro C. \& Gómez-Moreno C. 1990. - Consequences of the iron-dependent formation of ferredoxin and flavodoxin on photosynthesis and nitrogen fixation on Anabaena strains. Photosynth. Res., $26: 119-125$.

Somerville G., Mikoryak C.A \& Reitzer L. 1999. - Physiological characterization of Pseudomonas aeruginosa during exotoxin A synthesis : Glutamate iron limitation and aconitase activity. $J$. Bacteriol., 181 : 1072-1078.

Staggs T.M. \& Perry R.D. 1991. - Identification and cloning of a fur regulatory gene in Yersinia pestis. J. Bacteriol., $173: 417-425$.

Thomas C.E. \& Sparling P.F. 1994. - Identification and cloning of a fur homologue from Neisseria meningitidis. Mol. Microbiol., $11: 725-737$.

Wooldridge K.G., Williams P.H. \& Ketley J.M. 1994 . - Iron-responsive genetic regulation in Campylobacter jejuni : cloning and characterization of a fur homologue. J. Bacteriol., 176 : $5852-5856$. 